\title{
Enteral feeding advancement and growth until 5 years in extremely preterm infants
}

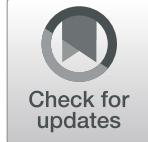

Cornelia Wiechers ${ }^{1}$, Jan-Niklas Doll ${ }^{1}$, Christoph Maas ${ }^{1}$, Kerstin Gründler ${ }^{1}$, Katja Büchner ${ }^{1}$, Christian F. Poets ${ }^{1 *}$ and Axel R. Franz ${ }^{1,2}$

\begin{abstract}
Background: In-utero weight gain can be achieved in very preterm infants through rapid advancement of enteral feeds without increasing risk of necrotizing enterocolitis. There are concerns, however, that such rapid weight gain may lead to an increased childhood adiposity risk, although long-term data are sparse.

Design: This retrospective observational study included two well-characterized cohorts comprising 145 infants born at $<28$ weeks or with $<1000 \mathrm{~g}$ birth weight. We investigated associations between advancing enteral feeding volumes in daily increments of $15-20 \mathrm{ml} / \mathrm{kg}$ (Cohort 1, $n=84$, born in 2006/2007) vs. 25$30 \mathrm{ml} / \mathrm{kg}$ (Cohort 2, $n=61$, born in 2010) and growth up to 5 years of age.

Results: There was no significant difference in anthropometric parameters post discharge to 5 years between both cohorts. Standard deviation score (SDS) weight and SDS BMI at the age of 5 years remained lower than in the reference population. SDS weight decreased from discharge to about 10-12 months postnatal age and returned to birth values by age 5 years. There was a catch-up for SDS length/ height from discharge to 5 years; SDS head circumference decreased from birth to 5 years. Multiple regression analyses revealed that for all anthropometric parameters SDS at birth was the most important predictor for SDS at 5 years. Early parenteral protein intake may be another important factor, at least for head growth.

Conclusions: Growth was similar in both cohorts without benefit from more accelerated feeding advancement in cohort 2. In both cohorts, early enteral nutrition was associated with in-hospital weight gain as in utero, a drop in weight SDS post discharge and catch-up to birth SDS until age 5 years, remaining below the reference population. Length showed catch-up form discharge to 5 years, whereas head circumference progressively deviated from the reference population. Increased parenteral protein supplementation may be needed to accompany early enteral feeding advancements.
\end{abstract}

Keywords: Infant, Neonatal, Premature, Nutrition, Enteral feeding, Growth outcome

\footnotetext{
*Correspondence: Christian-F.Poets@med.uni-tuebingen.de

'Department of Neonatology, University Children's Hospital, Eberhard Karls University, Tuebingen, Calwerstr. 7, 72076 Tuebingen, Germany

Full list of author information is available at the end of the article
}

(c) The Author(s). 2021 Open Access This article is licensed under a Creative Commons Attribution 4.0 International License, which permits use, sharing, adaptation, distribution and reproduction in any medium or format, as long as you give appropriate credit to the original author(s) and the source, provide a link to the Creative Commons licence, and indicate if changes were made. The images or other third party material in this article are included in the article's Creative Commons licence, unless indicated otherwise in a credit line to the material. If material is not included in the article's Creative Commons licence and your intended use is not permitted by statutory regulation or exceeds the permitted use, you will need to obtain permission directly from the copyright holder. To view a copy of this licence, visit http://creativecommons.org/licenses/by/4.0/. The Creative Commons Public Domain Dedication waiver (http://creativecommons.org/publicdomain/zero/1.0/) applies to the data made available in this article, unless otherwise stated in a credit line to the data. 


\section{Background}

Intensive nutritional support for preterm infants improves growth and thereby potentially neurodevelopment [1-3]. Therefore, most pediatric societies recommend that postnatal growth in the NICU should match that observed in utero [4].

Reaching this goal may require intensified enteral nutrition and faster feeding advancements, thereby also reducing time with intravenous access and parenteral nutrition, and the risk of sepsis and cholestasis [5]. The optimal rate of enteral feeding advancements in preterm infants is yet unknown, but available data suggest that advancing enteral feeding volumes at daily increments of $30-40 \mathrm{ml} / \mathrm{kg}$ does not increase the risk of necrotizing enterocolitis (NEC) or death even in very preterm or growth-restricted infants [5-8].

Especially after rapid advancement of enteral feeding volumes, there is concern that preterm infants' growth could be impaired by the variability in protein and energy content of human milk or insufficient enteral macronutrient absorption immediately after birth [9]. In a recent large randomized trial involving 2804 preterm infants, no difference could be found in developmentally intact survival at 24 months with a strategy of advancing milk feeding volumes in daily increments of $30 \mathrm{ml} / \mathrm{kg}$ as compared to $18 \mathrm{ml} / \mathrm{kg}$ [7]. However, long-term data on growth in later childhood and metabolic outcome of premature infants after accelerated enteral feeding advancement are sparse.

We studied the effect of accelerated enteral feeding advancements in infants born at $<32 \mathrm{wk}$. gestation or with birth weights $<1500 \mathrm{~g}$ [8]. Time to full enteral feeds was significantly shorter in the cohort with faster advancement of enteral feeding volumes (6 vs. 8 days), while NEC rates were similar (3.3 vs. $2.7 \%$ ). In contrast to published data reporting extrauterine growth restriction among most very preterm infants [10-14], both study cohorts continued to grow along their intrauterine percentiles. Better head circumference growth in the cohort with slower enteral feeding advancement was associated with higher parenteral protein administration in the first postnatal week [8].

We now aimed to investigate the effects of accelerated enteral feeding advancements on growth between hospital discharge and age 5 years in extremely preterm or extremely low birth weight infants previously described including details on postnatal nutrition [8].

\section{Methods}

\section{Participants/ study population}

This was a retrospective, single center observational study of extremely premature infants $(<28 \quad 0 / 7$ weeks gestation age or with birth weight $<1000 \mathrm{~g}$ ) born between January 2006 and December 2007 or between
January 2010 and December 2010 at Tuebingen University Women's and Children's Hospital, Germany, limited to infants who survived to discharge home. In cohort 1 , eight infants died before and three after discharge and in cohort 2, seven infants died before and no infant died after discharge. Infants who died were not included in this study. The initial course of both cohorts has been extensively described [8]. Infants with congenital malformations of the gastrointestinal tract, death before age 5 years or transfer to another hospital before achieving full enteral feeds were excluded.

\section{Data collection}

Clinical and anthropometric data between birth and discharge were determined daily. Furthermore, exact nutritional intakes were evaluated daily for the first 28 days after birth. Children's growth data between hospital discharge and age 5 years were collected during routine inhouse follow-up and additionally by means of a parental questionnaire collecting data from the child's routine developmental screening examinations designated by German law. The time intervals for these screening examinations are at 6 to 7 months of postnatal age (S1), 10 to 12 months (S2), 21 to 24 months (S3), 46-48 months (S4) and 60-64 months (S5).

\section{Ethics}

The Institutional Review Board approved the study protocol and written informed parental consent was obtained (project number: 210/2018BO2).

\section{Enteral nutrition policy}

The previously established feeding protocol was replaced by a revised version in 2009 to allow for an even faster advancement of enteral feeding volumes, changes to our feeding protocol are described in Table 1 and by Maas et al. [8]. According to the modified feeding protocol, preterm infants were divided into cohort 1 (2006-2007) and cohort 2 (2010).

Feeding own mother's milk was encouraged; if no breast milk was available, formula was fed (Beba, Nestlé). In both cohorts, enteral feeds started within $4 \mathrm{~h}$ and parenteral nutrition immediately after birth. Full enteral feeds were defined as $\geq 140 \mathrm{ml} / \mathrm{kg} / \mathrm{d}$ administered for 24 consecutive hours. To calculate macronutrient supply, we assumed a protein content in human milk of $1.4 \mathrm{~g} /$ $100 \mathrm{ml}$ and $67 \mathrm{kcal} / 100 \mathrm{ml}$.

Calculation of standard deviation scores (SDS) for weight $\left(S D S_{W}\right)$, length $\left(S D S_{L}\right)$ and head circumference $\left(S D S_{H C}\right)$

Anthroprometric parameters were computed using LM S growth (version 2.14; h t t p: / / w w . healthforallchildren.com/?product=lmsgrowth). The reference population was the British 1990 growth reference 
Table 1 Differences in feeding protocols between cohorts

\begin{tabular}{lll}
\hline & Cohort 1 & Cohort $\mathbf{2}$ \\
\hline Start of enteral feeds within 4 h of birth & $10-15 \mathrm{ml} / \mathrm{kg} / \mathrm{d}$ & $20 \mathrm{ml} / \mathrm{kg} / \mathrm{d}$ \\
Increase in daily enteral feeding volume & $15-20 \mathrm{ml} / \mathrm{kg} / \mathrm{day}$ & $25-30 \mathrm{ml} / \mathrm{kg} / \mathrm{day}$ \\
$\begin{array}{l}\text { Cut-off for of gastric residual volume considered "normal" } \\
\text { (in infants with unremarkable abdominal clinical status) }\end{array}$ & $1-2 \mathrm{ml} / \mathrm{kg}$ & $<4 \mathrm{ml} / \mathrm{kg}$ \\
Start of breast milk fortification (FM85, Nestle, Frankfurt) at enteral feeding intake & $\geq 150 \mathrm{ml} / \mathrm{kg} / \mathrm{d}$ & $\geq 100 \mathrm{ml} / \mathrm{kg} / \mathrm{d}$ \\
Parenteral protein administration (day1) & $2.5 \mathrm{~g} / \mathrm{kg} / \mathrm{day}$ & $3.0 \mathrm{~g} / \mathrm{kg} / \mathrm{d}$ \\
\hline
\end{tabular}

$[15,16]$ fitted by maximum penalized likelihood as described before [15].

\section{Statistical analyses}

Data are presented as mean (standard deviation, SD) if normally distributed, or as median and interquartile range if not. In case that within a table a minority of parameters were normally distributed, the data are still presented as median (interquartile range) to improve clarity of presentation. Comparisons between groups were performed using a two-sided t-test or ANOVA and post hoc Tukey's multiple comparison test for normally distributed variables or Wilcoxon test in non-normally distributed data and Chi-square test for categorical outcomes. Multiple linear regression analysis was performed to identify important influencing factors on $\mathrm{SDS}_{\mathrm{W}}, \mathrm{SDS}_{\mathrm{L}}$ and $\mathrm{SDS}_{\mathrm{HC}}$ at 5 years including study cohort, sex, gestational age and SDS at birth, and based on our previous analysis [8] cumulative parenteral protein intake until $28 \mathrm{~d}$, as independent variables. Despite a difference in the proportion of multiple births between cohorts, we did not include multiple births into this analysis because the main effect being a multiple should be on birth weight (not on postnatal growth) and for each anthropometric measure the corresponding SDS at birth was included. Analyses were performed with GraphPad Prism ${ }^{\circ}$ 8.1.0 (GraphPad Software, San Diego, CA, USA) and SAS 9.4, the level of significance was $p<0.05$.

\section{Results}

\section{Participants}

A total of 163 premature infants with gestational age < 28 weeks or birth weight $<1000 \mathrm{~g}$ were admitted to our hospital during the two study periods; 18 (11.0\%) died before age 5 years and were thus excluded from analysis (11/95 (11.6\%) in cohort $1,7 / 68(10.3 \%)$ in cohort 2$)$. No infant had a severe congenital malformation of the gastrointestinal tract. Demographic data of the study population are shown in Table 2. Complete anthropometric data were available for all 145 infants at birth and discharge, the proportion of infants with documented growth data at the time of S1 (at 6-7 months) was 90\% and decreased in the following periods: S2: $86 \%$, S3: $82 \%$, S4: 69\%, S5: 65\% (Tables 3 and 4).
In Cohort 1, the proportion of multiple births and gestational age at birth were lower than in cohort $2(26 \%$ vs. $59 \%, p<0.0001$, and 26.1 vs. 27.0 wk., $p=0.037$, respectively). Full enteral feeds were established significantly later in cohort 1 (median 9th vs. 7th postnatal day, $p<0.0001$; Table 1). Cumulative energy and cumulative protein intake were lower whereas cumulative parenteral protein intake was higher in Cohort 1 than in Cohort 2 (all $p<0.01$, Table 2). There was no difference in the length of hospital stay (Table 2). Median duration with peripherally inserted central venous access and with peripheral venous access were both shorter in cohort 2 ( $p=0.006$ and $p=0.044$; Table 2).

Median SDS $_{\mathrm{W}}$ Birth was similar with - 1.17 (-2.09 $-0.23)$ in cohort 1 and $-1.40(-2.24--0.61)$ in cohort 2. $23 / 84$ infants (27\%) in cohort 1 and 20/61 (33\%) in cohort 2 were born small for gestational age with a weight less than 2 standard deviations below the mean (Table 3, Fig. 1). Differences in SDS from birth to discharge and to age 5 years, respectively, were close to zero and not different between cohorts (Table 4). However, SDS $\mathrm{W}_{\mathrm{W}}$ decreased post discharge with a nadir for $\mathrm{SDS}_{\mathrm{W}}$ at S2 (1012 months after birth or 6-8 months post discharge) and a recovery towards birth values by 5 years. By contrast, there was a steady decline in $\operatorname{SDS}_{\mathrm{HC}}$ and a continuous catch-up of $\mathrm{SDS}_{\mathrm{L}}$ from discharge to age 5 years (Fig. 1).

On multiple linear regression analysis, $\mathrm{SDS}_{\mathrm{W}}, \mathrm{SDS}_{\mathrm{L}}$, $\mathrm{SDS}_{\mathrm{HC}}$ at birth were the most important influencing factors for $\mathrm{SDS}_{\mathrm{W}}, \mathrm{SDS}_{\mathrm{L}}, \mathrm{SDS}_{\mathrm{HC}}$ at 5 years. However, $\mathrm{r}^{2}$ was only $0.16,0.32$ and 0.21 respectively (Table 5 ). Cumulative parenteral protein intake at $\mathrm{d} 1-\mathrm{d} 28$ was a significant predictor of $\mathrm{SDS}_{\mathrm{HC}}$ at 5 years.

\section{Discussion}

The aims of this study were to analyze and describe growth in extremely preterm infants during the first 5 years after birth following accelerated enteral feeding advancement and in-hospital weight gain as in utero, and to investigate factors potentially influencing anthropometric data until 5 years of age. Median postnatal age at full feeds (defined as $\geq 140 \mathrm{ml} / \mathrm{kg} / \mathrm{d}$ administered for 24 consecutive hours) was 9 days and 7 days in these extremely preterm or extremely low birth weight infants. 
Table 2 Characteristics of study cohorts

\begin{tabular}{|c|c|c|c|}
\hline & & $\begin{array}{l}\text { Cohort } 1 \\
n=84\end{array}$ & $\begin{array}{l}\text { Cohort } 2 \\
n=61\end{array}$ \\
\hline Female & n (\%) & $48(57 \%)$ & $38(62 \%)^{e}$ \\
\hline Gestational age at birth (weeks) & Median (Q1, Q3) & $26.1(24.9-27.6)$ & $27.0(26.0-27.7)^{e}$ \\
\hline Birth weight (g) & Median (Q1, Q3) & 740 (597-932) & $785(620-980)$ \\
\hline Birth length (cm) & Median (Q1, Q3) & $33(31-35)$ & $33(31-35)$ \\
\hline Birth head circumference $(\mathrm{cm})$ & Median (Q1, Q3) & $22.5(22.0-25.0)$ & $24.0(22.5-25.7)$ \\
\hline Infants from multiple pregnancies & n (\%) & $22(26.2 \%)$ & $36(59.0 \%)^{\mathrm{e}}$ \\
\hline Twins & $n(\%)$ & $18(21.4 \%)$ & $28(45.9 \%)$ \\
\hline Triplets & $\mathrm{n}(\%)$ & $4(4.8 \%)$ & $8(13.1 \%)$ \\
\hline Length of hospital stay (days) & Median (Q1, Q3) & $89(64-109)$ & $77(55-102)$ \\
\hline Postmenstrual age at discharge (weeks) & Median (Q1, Q3) & $39.3(37.2-41.0)$ & $38.4(36.0-40.7)$ \\
\hline \multicolumn{4}{|l|}{ Neonatal morbidities } \\
\hline Necrotizing enterocolitis ${ }^{\mathrm{b}}$ & n (\%) & $2(2.4 \%)$ & $2(3.3 \%)$ \\
\hline Focal intestinal perforation & n (\%) & $5(6.0 \%)$ & $2(3.3 \%)$ \\
\hline Intraventricular hemorrhage $\geq|| \mid$ & n (\%) & $7(8.3 \%)$ & $2(3.3 \%)$ \\
\hline Periventricular leukomalacia & n (\%) & $1(1.2 \%)$ & $3(4.9 \%)$ \\
\hline Bronchopulmonary dysplasia $^{a}$ & n (\%) & $21(25 \%)$ & $14(23 \%)$ \\
\hline Retinopathy of Prematurity requiring therapy & n (\%) & $8(9.5 \%)$ & $2(3.2 \%)$ \\
\hline \multicolumn{4}{|l|}{ Total time with ${ }^{c}$} \\
\hline Peripheral venous line (days) & Median (Q1, Q3) & $11(7-19)$ & $9(5-15)^{e}$ \\
\hline Central venous line (days) & Median (Q1, Q3) & $6(0-14)$ & $0(0-6)^{\mathrm{e}}$ \\
\hline Antibiotic treatment (days) & Median (Q1, Q3) & $10(5-22)$ & $9(5-17)$ \\
\hline \multicolumn{4}{|l|}{ Nutrition } \\
\hline Day of life when full enteral feeds were attained & Median (Q1, Q3) & $9(8-11)$ & $7(6-9)^{e}$ \\
\hline \multicolumn{4}{|l|}{ Cumulative protein intake $(\mathrm{g} / \mathrm{kg})$} \\
\hline First postnatal week & Median & $25.5(23.4-27.0)$ & $24.2(22.3-27.3)$ \\
\hline First postnatal 28 days & (Q1, Q3) & $104.6(99.8-108.1)$ & $109.0(103.1-115.0)^{\mathrm{e}}$ \\
\hline \multicolumn{4}{|l|}{ Cumulative parenteral protein intake $(\mathrm{g} / \mathrm{kg})$} \\
\hline First postnatal week & Median (Q1, Q3) & $17.9(15.7-20.0)$ & $10.7(8.3-15.0)^{\mathrm{e}}$ \\
\hline First postnatal 28 days & Median (Q1, Q3) & $22.8(17.1-30.3)$ & $12.8(8.3-22.7)^{\mathrm{e}}$ \\
\hline \multicolumn{4}{|l|}{ Cumulative energy intake (kcal/kg) } \\
\hline First postnatal week & Median (Q1, Q3) & $592(529-625)$ & $653(577-721)^{\mathrm{e}}$ \\
\hline First postnatal 28 days & Median (Q1, Q3) & $3358(3109-3490)$ & $3442(3266-3673)^{e}$ \\
\hline \multicolumn{4}{|l|}{ Nutrition at discharge } \\
\hline Mother's own milk $100 \%$ & n (\%) & $25(30 \%)$ & $32(53 \%)^{\mathrm{e}}$ \\
\hline Mother's own milk ${ }^{d}$ Formula & n (\%) & $18(21 \%)$ & $14(23 \%)$ \\
\hline Formula $100 \%$ & n (\%) & $41(49 \%)$ & $15(25 \%)^{e}$ \\
\hline Nutrition at 3 months follow up & & $n=67$ & $n=54$ \\
\hline Mother's own milk $100 \%$ & n (\%) & $6(9 \%)$ & $11(20 \%)$ \\
\hline Mother's own milk ${ }^{\mathrm{d}}$ Formula & $n(\%)$ & $10(15 \%)$ & $6(11 \%)$ \\
\hline Formula $100 \%$ & n (\%) & $51(76 \%)$ & $37(69 \%)$ \\
\hline Duration of expressed breast milk/breastfeeding (months) & & $n=39$ & $n=45$ \\
\hline Based on questionnaire & Median (Q1, Q3) & $5(3-9)$ & $5(4-9)$ \\
\hline
\end{tabular}

Cohort 1 (2006-2007): enteral feeds were initiated on day 1 with 10-15 ml/kg/day and advanced by $15-20 \mathrm{ml} / \mathrm{kg} /$ day

Cohort 2 (2010): enteral feeds were initiated on day 1 with $20 \mathrm{ml} / \mathrm{kg} /$ day and advanced by $25-30 \mathrm{ml} / \mathrm{kg} / \mathrm{day}$

a Moderate or severe BPD according to consensus definition based on oxygen supplementation or positive pressure respiratory support at 36 weeks PMA

${ }^{b} \geq$ lla according to Bell criteria

c During the entire inpatient stay

d Supplemented with human milk fortifier

${ }^{\mathrm{e}}$ Significantly different between the two cohorts ( $p<0.05$ by Chi-square and Mann-Whitney-Test, respectively) 
Table 3 Weight, SDS weight, SDS length/height, SDS head circumference and SDS BMI from birth to age five years

\begin{tabular}{|c|c|c|c|c|c|c|c|c|c|c|c|c|}
\hline \multirow[t]{2}{*}{ Time } & \multicolumn{6}{|c|}{ Cohort 1} & \multicolumn{6}{|c|}{ Cohort 2} \\
\hline & $n$ & $\begin{array}{l}\text { Weight } \\
(\mathrm{kg})\end{array}$ & $\begin{array}{l}\text { SDS } \\
\text { weight }\end{array}$ & $\begin{array}{l}\text { SDS } \\
\text { length/ } \\
\text { height }\end{array}$ & $\begin{array}{l}\text { SDS head } \\
\text { circumference }\end{array}$ & SDS BMI & $n$ & $\begin{array}{l}\text { Weight } \\
\text { (kg) }\end{array}$ & $\begin{array}{l}\text { SDS } \\
\text { weight }\end{array}$ & $\begin{array}{l}\text { SDS } \\
\text { length/ } \\
\text { height }\end{array}$ & $\begin{array}{l}\text { SDS head } \\
\text { circumference }\end{array}$ & SDS BMI \\
\hline Birth & 84 & $\begin{array}{l}0.740 \\
(0.597- \\
0.932)\end{array}$ & $\begin{array}{l}-1.17(- \\
2.09- \\
-0.23)\end{array}$ & $\mathrm{N} / \mathrm{A}$ & $\begin{array}{l}-1.39(-2.04- \\
-0.50)\end{array}$ & N/A & 61 & $\begin{array}{l}0.785 \\
(0.620- \\
0.980)\end{array}$ & $\begin{array}{l}-1.40(- \\
2.24- \\
-0.61)\end{array}$ & $\mathrm{N} / \mathrm{A}$ & $\begin{array}{l}-1.16(-2.06- \\
-0.52)\end{array}$ & $\mathrm{N} / \mathrm{A}$ \\
\hline Discharge & 84 & $\begin{array}{l}2.692 \\
(2.370- \\
3.044)\end{array}$ & $\begin{array}{l}-1.24(- \\
2.01- \\
-0.69)\end{array}$ & $\begin{array}{l}-2.24(- \\
3.17- \\
-1.58)\end{array}$ & $\begin{array}{l}-0.72(-1.55- \\
0.09)\end{array}$ & $\begin{array}{l}0.27(- \\
0.38-1.02)\end{array}$ & 61 & $\begin{array}{l}\mathbf{2 . 5 3 0} * \\
(2.028- \\
2.858)\end{array}$ & $\begin{array}{l}-1.42(- \\
2.35- \\
-0.68)\end{array}$ & $\begin{array}{l}-2.65(- \\
3.39- \\
-1.75)\end{array}$ & $\begin{array}{l}-1.17^{*}(-2.06 \\
--0.76)\end{array}$ & $\begin{array}{l}0.18(- \\
0.41-1.01)\end{array}$ \\
\hline $\begin{array}{l}\text { S1 (6-7 } \\
\text { months) }\end{array}$ & 74 & $\begin{array}{l}5.22 \\
(4.74- \\
5.85)\end{array}$ & $\begin{array}{l}-1.47(- \\
2.21- \\
-0.77)\end{array}$ & $\begin{array}{l}-1.31(- \\
1.85- \\
-0.41)\end{array}$ & $\begin{array}{l}-0.81(-1.7- \\
-0.10)\end{array}$ & $\begin{array}{l}-1.09(- \\
1.72- \\
-0.36)\end{array}$ & 56 & $\begin{array}{l}5.02 \\
(4.56-5.80)\end{array}$ & $\begin{array}{l}-1.84(- \\
2.54- \\
-0.81)\end{array}$ & $\begin{array}{l}-1,35(- \\
2.25- \\
-0.26)\end{array}$ & $\begin{array}{l}-1.19(-2.02- \\
-0.49)\end{array}$ & $\begin{array}{l}-1.52(- \\
2.16- \\
-0.46)\end{array}$ \\
\hline $\begin{array}{l}\text { S2 (10-12 } \\
\text { months) }\end{array}$ & 74 & $\begin{array}{l}7.31 \\
(6.66- \\
8.21)\end{array}$ & $\begin{array}{l}-1.68(- \\
2.62- \\
-1.00)\end{array}$ & $\begin{array}{l}-0.75(- \\
1.26-0.18)\end{array}$ & $\begin{array}{l}-1.40(-2.22- \\
-0.85)\end{array}$ & $\begin{array}{l}-1.67(- \\
2.8- \\
-0.98)\end{array}$ & 52 & $\begin{array}{l}7.09 \\
(6.29-7.98)\end{array}$ & $\begin{array}{l}-2.07(- \\
3.17- \\
-0.99)\end{array}$ & $\begin{array}{l}-0.61(- \\
1.47-0.25)\end{array}$ & $\begin{array}{l}-1.69(-2.75- \\
-1.13)\end{array}$ & $\begin{array}{l}-2.06(- \\
2.92- \\
-1.16)\end{array}$ \\
\hline $\begin{array}{l}\text { S3 (21-24 } \\
\text { months) }\end{array}$ & 74 & $\begin{array}{l}10.00 \\
(9.36- \\
10.92)\end{array}$ & $\begin{array}{l}-1.46(- \\
2.16- \\
-0.77)\end{array}$ & $\begin{array}{l}-0.74(- \\
1.35- \\
-0.09)\end{array}$ & $\begin{array}{l}-1.67(-2.46- \\
-0.75)\end{array}$ & $\begin{array}{l}-1.44(- \\
2.36- \\
-0.64)\end{array}$ & 45 & $\begin{array}{l}9.53 \\
(8.62- \\
10.50)\end{array}$ & $\begin{array}{l}-1.79(- \\
3.09- \\
-1.13)\end{array}$ & $\begin{array}{l}-0.65(- \\
1.84- \\
-0.06)\end{array}$ & $\begin{array}{l}-2.12(-2.90- \\
-1.37)\end{array}$ & $\begin{array}{l}-1.91(- \\
2,77- \\
-0.77)\end{array}$ \\
\hline $\begin{array}{l}\text { S4 (46-48 } \\
\text { months) }\end{array}$ & 58 & $\begin{array}{l}13.65 \\
(12.42- \\
15.00)\end{array}$ & $\begin{array}{l}-1.30(- \\
2.11- \\
-0.35)\end{array}$ & $\begin{array}{l}-0.32(- \\
0.92-0.32)\end{array}$ & $\begin{array}{l}-1.89(-2.52- \\
-1.25)\end{array}$ & $\begin{array}{l}-1.48(- \\
2.23- \\
-0.7)\end{array}$ & 42 & $\begin{array}{l}13.50 \\
(12.00- \\
15.00)\end{array}$ & $\begin{array}{l}-1.51(- \\
2.35-- \\
0.39)\end{array}$ & $\begin{array}{l}-0.39(- \\
1.14-0.07)\end{array}$ & $\begin{array}{l}-2.09(-3.23- \\
-1.31)\end{array}$ & $\begin{array}{l}-1.76(- \\
2.18- \\
-0.79)\end{array}$ \\
\hline $\begin{array}{l}\text { S5 (60-64 } \\
\text { months) }\end{array}$ & 51 & $\begin{array}{l}16.00 \\
(14.35- \\
18.00)\end{array}$ & $\begin{array}{l}-1.08(- \\
1.91- \\
-0.06)\end{array}$ & $\begin{array}{l}-0.16(- \\
1.02-0.28)\end{array}$ & $\begin{array}{l}-1.78(-2.66- \\
-1.17)\end{array}$ & $\begin{array}{l}-1.14(- \\
1.87- \\
-0.46)\end{array}$ & 43 & $\begin{array}{l}15.65 \\
(13.80- \\
17.57)\end{array}$ & $\begin{array}{l}-1.51(- \\
2.36- \\
-0.35)\end{array}$ & $\begin{array}{l}-0.65(- \\
1.58-0.13)\end{array}$ & $\begin{array}{l}-2.17(-3.04- \\
-1.38)\end{array}$ & $\begin{array}{l}-1.27(- \\
2.10- \\
-0.71)\end{array}$ \\
\hline
\end{tabular}

All data presented as median (Q1, Q3), N/A not available (SDS length and SDS BMI could not be computed before term)

Abbreviations: Body mass index (BMI), Standard deviation score (SDS)

* Significantly different between the two cohorts ( $p<0.05$; Mann-Whitney-Test)

Child's routine developmental screening examinations: S1: 6 to 7 months after birth, S2: 10 to 12 months after birth, S3: 21 to 24 months after birth, S4: 46-48 months after birth, S5: 60-64 months after birth

Overall, no differences in growth pattern up to 5 years of age were found between the two cohorts with different feeding regimens. Compared to the reference population, the preterm infants studied here had a significantly lower $\mathrm{SDS}_{\mathrm{W}}, \mathrm{SDS}_{\mathrm{L}}$ and $\mathrm{SDS}_{\mathrm{HC}}$ at birth. There were no differences in $\mathrm{SDS}_{\mathrm{W}}$ between the two cohorts throughout the observational period. In Cohort 1 , with slower daily feeding increments and higher parenteral protein intake during the first postnatal week, a better early postnatal head circumference growth was observed until discharge [8]. At age 5 years, this difference in head circumference and in change in $\mathrm{SDS}_{\mathrm{HC}}$ was no longer evident. Nevertheless, cumulative parenteral protein intake after birth remained significantly associated with $\mathrm{SDS}_{\mathrm{HC}}$ at 5 years in multiple linear regression analysis and $\mathrm{SDS}_{\mathrm{HC}}$ progressively decreased up to age 5 years. As a consequence of this finding we have increased parenteral protein supplementation during the postnatal transition to full enteral feeds, but additional nutritional interventions (e.g., supplementation with choline and polyunsaturated fatty acids) should also be considered [17-20]. Catch-up growth occurred only for $\mathrm{SDS}_{\mathrm{L}}$ in both cohorts, showing values within the reference range at age 5 years.

A Swedish follow-up study of 83 extremely preterm infants came to similar results: weight showed a sharp decrease in z-scores from birth to 3 months' corrected age, followed by catch-up growth up to age 11 years, but weight remained lower than in term-born controls (mean (SD) z score: at birth - $0.57(0.98)$, at due date $1.62(0.76)$, at 3 months $-2.27(1.38)$, at 5 years -0.77 (1.35) and at 11 years $-0.15(1.22)$ ) [21]. Z-scores for height decreased up to 3 months corrected age $(-2.24$ (1.32)), followed by catch-up growth up to 11 years (0.53 (1.08). Head circumference also showed no catchup growth and remained significantly lower than in control participants at all ages, mean $\mathrm{z}$-Score $\mathrm{HC}_{\mathrm{HC}}$ at birth was $-1.30(0.71)$ and - 1.11 (1.06) at 11 years of age.

Contrary to our and the Swedish findings, many studies reported that preterm infants with postnatal growth retardation up to discharge regain weight in the following months, with catch up to their peers by the time of reaching school age $[10,21]$.

As currently recommended [4], both study cohorts matched in-utero weight gain during their stay in the NICU with a delta-SDS ${ }_{\mathrm{W}}$ from birth to discharge of close to zero; likewise the change in $\mathrm{SDS}_{\mathrm{W}}$ from birth to age 5 years was close to zero. The $\operatorname{SDS}_{\mathrm{BMI}}$ at age 5 years was significantly lower than at discharge and lower than that of the reference population, but again not different between cohorts. Presumably, there were no differences in growth pattern up to age 5 years between the two 
Table 4 SDS-Difference from birth to discharge and to age five years

\begin{tabular}{lll}
\hline Difference of SDS & Cohort 1 & Cohort 2 \\
\hline SDS $_{\text {discharge }}-$ SDS $_{\text {birth }}$ & & \\
Weight & $-0.11(-0.83-0.37)$ & $-0.15(-0.61-0.35)$ \\
Head circumference & $0.48(-0.32-1.30)$ & $-\mathbf{0 . 2 0}(-0.71-0.75)$ \\
Length & $\mathrm{N} / \mathrm{A}$ & $\mathrm{N} / \mathrm{A}$ \\
BMl & $\mathrm{N} / \mathrm{A}$ & $\mathrm{N} / \mathrm{A}$ \\
SDS $_{\text {S5 }}-$ SDS $_{\text {birth }}$ & & \\
Weight $_{\text {Head circumference }}$ & $-0.9(-1.7-0.0)$ & $-0.8(-1.7--0.1)$ \\
Length/height & $\mathrm{N} / \mathrm{A}$ & $\mathrm{N} / \mathrm{A}$ \\
BMl & $\mathrm{N} / \mathrm{A}$ & $\mathrm{N} / \mathrm{A}$ \\
SDS $_{\text {S5 }}-$ SDS & & \\
Weigcharge & & $0.0(-0.6-0.7)$ \\
Head circumference & $-1.3(-2.1--0.5)$ & $-1.2(-1.6-0.1)$ \\
Length/height & $2.0(1.0-2.8)$ & $1.8(1.1-2.4)$ \\
BMl & $-1.5(-2.2--0.6)$ & $-1.5(-2.0--0.7)$
\end{tabular}

All data presented as median (Q1, Q3).

*Significantly different between the two cohorts $(p<0.05$ by Mann-Whitney-Test)

N/A not available (SDS for length and for BMI could not be computed at birth before term).

Abbreviations: Body mass index (BMI), Standard deviation score (SDS), SDS S5: $60-64$ months after birth $\left(\right.$ SDS $\left._{\mathrm{S} 5}\right)$

cohorts because time to establish full enteral feeds was similarly short and cumulative protein intake until d28 was similarly high and higher than in most previous studies reporting increased weight gain with increased protein intake $[1,11]$. Recently published randomized controlled trials on the effect of increased protein supplementation on growth of very preterm infants have shown that increasing protein intake by $0.6 \mathrm{~g} / \mathrm{kg} / \mathrm{d}$ to an intake of $4.3 \mathrm{~g} / \mathrm{kg} / \mathrm{d}$ does not further promote growth until discharge, possibly due to a ceiling effect $[22,23]$.

In contrast to our findings, most studies report that preterm infants fail to achieve near in-utero weight gain during their NICU stay [10-12, 21, 24]. A number of studies demonstrated an association between impaired postnatal growth in preterm infants and neurodevelopmental disabilities, hence the importance of early and adequate nutrition in this period of rapid growth [1-3].

Beyond neurocognitive development, it has been suspected that disturbances in intrauterine growth can have long-term effects on adult health, e.g., an increased risk for hypertension and insulin resistance, likely based on mechanisms of fetal programming and epigenetics [25, 26]. However, it is unclear whether extrauterine growth restriction in preterm infants has similar effects as fetal growth restriction $[24,27,28]$. For example, a higher prevalence of insulin resistance and glucose intolerance and increased systolic blood pressure have been described in 163 very low birth weight (VLBW) infants at age 18-27 years compared to young adults who were born at term [24]. In that study, extrauterine/postnatal weight gain was poor and mean SDS change from birth to term $-1.4 \pm 1.32$, very different from our observations. In a randomized study including 50 VLBW infants, a significant improvement in postnatal growth without Z-score loss from birth to 36 weeks corrected age was found with increased compared to standard nutrient supply [29]. In that study, adiponectin concentrations at 5 months corrected age were higher with increased nutrient supply and this correlated positively with early weight gain, where increased adiponectin levels are generally associated with a lower risk of obesity and metabolic syndrome in children [29, 30]. Early nutrition and growth may therefore influence metabolic markers in infancy and early childhood. The long-term metabolic effects of an in-hospital growth pattern mimicking intrauterine growth on cardiovascular and metabolic health require further study.

Limitations of our study include its retrospective and single-center design and up to $35 \%$ loss to follow-up until age 5 years. Potentially, the latter could introduce attrition bias and thus affect the validity of our observations, however, mean GA at birth of those followed to age 5 years and of the initial cohorts were similar. For this study, we deliberately did not contact parents whose children had already died before age 5 years, consequently our data only apply to infants who survive to 5 years. Furthermore, this study is obviously limited to survivors, the growth data of the sickest preterm infants, who died before discharge, have not been included. Although this is a retrospective cohort study in two periods 3-4 years apart, there were no significant changes in management between the two cohorts described, apart from modifying the feeding protocol. Remarkably, however, in cohort 1 the proportion of multiple births and gestational age were lower than in cohort 2, although we did not find an explanation for this increase.

Strengths include our well-described nutritional regimen and detailed information on nutritional support during the first 28 postnatal days, and that both cohorts included an unselected population of extremely low birth weight (ELBW) infants with intensified and very early enteral nutrition resulting in an early postnatal growth along their intrauterine percentiles during their NICU stay.

\section{Conclusion}

Both cohorts attained full enteral feeds much earlier than previously reported and weight gain as in utero was achieved. There was no significant difference in anthropometric parameters after discharge between both cohorts, but there was catch-up for SDS length/height 

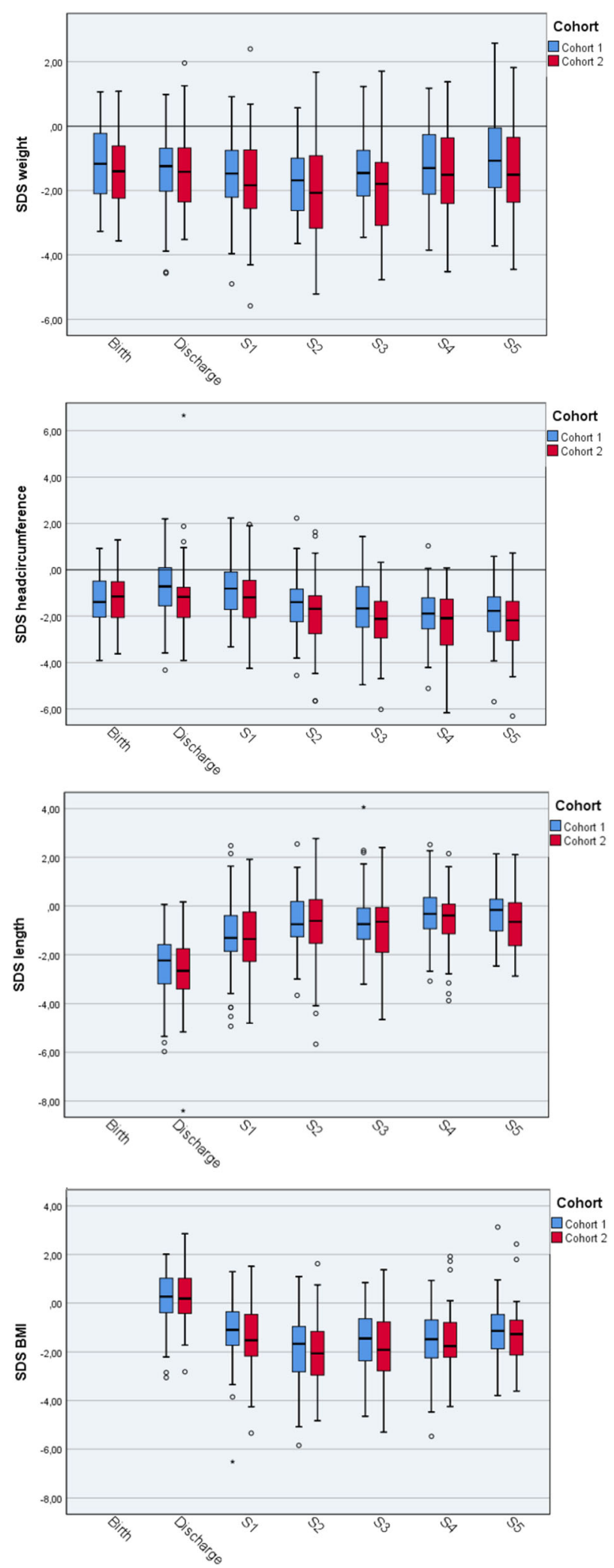

Fig. 1 SDS for weight, head circumference, length/height and BMl from birth to age five years (S5) 
Table 5 Potential influencing factors for SDS at age 5 years by multiple linear regression

\begin{tabular}{|c|c|c|c|c|c|c|}
\hline & Influence or & & Influence & $S_{\mathrm{HC}}$ & Influence & \\
\hline & $r^{2}=0.1573$ & & $r^{2}=0.321$ & & $r^{2}=0.207$ & \\
\hline & Estimate & $p$-value & Estimate & $p$-value & Estimate & $p$-value \\
\hline Intercept & -5.751 & 0.0322 & -0.5291 & ns & 0.4486 & ns \\
\hline Gestational age at birth & 0.1915 & ns & -0.01476 & ns & -0.01206 & ns \\
\hline SDS at birth ${ }^{a} /$ at discharge ${ }^{b}$ & 0.4286 & 0.0041 & 0.4930 & 0.0058 & 0.3374 & 0.0004 \\
\hline Gender & 0.3009 & ns & 0.7060 & ns & -0.09560 & ns \\
\hline Cohort1/2 & -0.3275 & ns & -0.5057 & ns & -0.2198 & ns \\
\hline Cumulative parenteral protein intake $\mathrm{d} 1 \mathrm{-d} 28$ & -0.0004704 & ns & -0.02922 & 0.0236 & 0.01227 & ns \\
\hline
\end{tabular}

Abbreviations: not significant (ns), Standard deviation score (SDS)

${ }^{a}$ For weight and head circumference; ${ }^{\text {b }}$ for length/height

from discharge to age 5 years. SDS weight and SDS BMI at age 5 years remained lower than in the reference population, SDS weight decreased from discharge to about 10-12 months and returned to birth values at age 5 years. SDS head circumference decreased from birth to 5 years, thus higher parenteral protein supplementation may be necessary during transition to full enteral feeds.

In summary, there is no evidence of an increased risk of obesity up to age 5 years following intensified nutritional support with rapid enteral feeding advancement and percentile-parallel weight gain during their NICU stay. Further follow up into adulthood is desirable.

\section{Abbreviations}

bw: Birth weight; EF : Enteral feeding; BMl : Body mass index;

ELBW: Extremely low birth weight $(<1000 \mathrm{~g})$; FIP: Focal intestinal perforation; N/A: Not available; NEC: Necrotizing enterocolitis; NICU: Neonatal intensive care unit; VLBW: Very low birth weight (<1500 g); SD : Standard deviation; SDS: Standard deviation score; SDS $_{w}$ birth: SDS weight at birth; SDS $_{w}$ s5: SDS weight five years of age; wk.: Week

\section{Acknowledgements}

We are grateful to Corinna Engel for their support in statistical analyses and we would like to thank Dr. Jörg Arand for his help to extract Data from the hospital quality assurance database.

\section{Clinical trial registration}

Not necessary due to the retrospective design.

\section{Sharing raw data}

The datasets generated and/or analysed during the current study are not publicly available because they were derived from the hospital's electronic patient files and ethics approval is conditional on publishing summary data only, but are available from the corresponding author on reasonable request.

\section{Authors'Contributions}

CW conceptualized and designed the study, drafted the initial manuscript, and reviewed and revised the manuscript. J-ND designed the data collection instruments, collected data, carried out the initial analyses, and reviewed, and revised the manuscript. KG, KB, CM contributed to conception of the study and revising the article critically for important intellectual content. CFP conceptualized and designed the study, supervised the project as the head of department and critically reviewed the manuscript for important intellectual content. ARF conceptualized and designed the study together with CW, CM and CFP, coordinated and supervised data collection, and critically reviewed the manuscript. All authors approved the final manuscript as submitted and agree to be accountable for all aspects of the work.

\section{Funding}

Publication of this manuscript was supported by the Open Access Publishing Fund of the University of Tuebingen. Open Access funding enabled and organized by Projekt DEAL.

\section{Declarations}

Ethics approval and consent to participate

The research was conducted ethically in accordance with the World Medical Association Declaration of Helsinki. Ethics approval for the study was given by the Ethics committee of the Medical Faculty of the University of Tuebingen (Project number: 210/2018BO2), Ethik Kommission, Eberhard Karls University, Gartenstraße 47, 72074 Tuebingen, Germany) and written informed parental consent was obtained.

Consent for publication

Not applicable.

\section{Competing interests}

The authors have no financial relationship relevant to this article to disclose. The authors declare that they have no competing interests.

\section{Author details}

${ }^{1}$ Department of Neonatology, University Children's Hospital, Eberhard Karls University, Tuebingen, Calwerstr. 7, 72076 Tuebingen, Germany. ${ }^{2}$ Center for Pediatric Clinical Studies, University Children's Hospital, Eberhard Karls University, Tuebingen, Germany.

Received: 28 March 2021 Accepted: 3 September 2021

Published online: 23 September 2021

\section{References}

1. Stephens BE, Walden RV, Gargus RA, Tucker R, McKinley L, Mance M, et al. First-week protein and energy intakes are associated with 18-month developmental outcomes in extremely low birth weight infants. Pediatrics. 2009:123(5):1337-43. https://doi.org/10.1542/peds.2008-0211.

2. Franz AR, Pohlandt F, Bode H, Mihatsch WA, Sander S, Kron M, et al. Intrauterine, early neonatal, and postdischarge growth and neurodevelopmental outcome at 5.4 years in extremely preterm infants after intensive neonatal nutritional support. Pediatrics. 2009;123(1):e101-9. https://doi.org/10.1542/peds.2008-1352.

3. Ehrenkranz RA, Dusick AM, Vohr BR, Wright LL, Wrage LA, Poole WK. Growth in the neonatal intensive care unit influences neurodevelopmental and growth outcomes of extremely low birth weight infants. Pediatrics. 2006; 117(4):1253-61. https://doi.org/10.1542/peds.2005-1368.

4. Agostoni C, Buonocore G, Carnielli VP, De Curtis M, Darmaun D, Decsi T, et al. Enteral nutrient supply for preterm infants: commentary from the European Society of Paediatric Gastroenterology, hepatology and nutrition committee on nutrition. J Pediatr Gastroenterol Nutr. 2010;50(1):85-91. https://doi.org/10.1097/MPG.0b013e3181adaee0.

5. Oddie SJ, Young L, McGuire W. Slow advancement of enteral feed volumes to prevent necrotising enterocolitis in very low birth weight infants. 
Cochrane Database Syst Rev. 2017;8:CD001241. https://doi.org/10.1002/14 651858.CD001241.pub7.

6. Maas C, Wiechers C, Bernhard W, Poets CF, Franz AR. Early feeding of fortified breast milk and in-hospital-growth in very premature infants: a retrospective cohort analysis. BMC Pediatr. 2013;13(1):178. https://doi.org/1 0.1186/1471-2431-13-178.

7. Dorling J, Abbott J, Berrington J, Bosiak B, Bowler U, Boyle E, et al. Controlled trial of two incremental Milk-feeding rates in preterm infants. N Engl J Med. 2019;381(15):1434-43. https://doi.org/10.1056/NEJMoa1816654.

8. Maas C, Mitt S, Full A, Arand J, Bernhard W, Poets CF, et al. A historic cohort study on accelerated advancement of enteral feeding volumes in very premature infants. Neonatology. 2013;103(1):67-73. https://doi.org/10.1159/ 000342223.

9. Schanler RJ, Shulman RJ, Lau C. Feeding strategies for premature infants: beneficial outcomes of feeding fortified human milk versus preterm formula. Pediatrics. 1999;103(6 Pt 1):1150-7. https://doi.org/10.1542/peds.1 03.6.1150.

10. Stutte S, Gohlke B, Peiler A, Schreiner F, Born M, Bartmann P, et al. Impact of early nutrition on body composition in children aged 9.5 years born with extremely low birth weight. Nutrients. 2017;9(2):124. https://doi.org/10.3390/ nu9020124.

11. Peiler A, Woelfle J, Stutte S, Schreiner F, Bartmann P, Gohlke B. Postnatal nutrition in extremely low birth weight infants and its impact on growth until the age of 6 years. Acta Paediatr. 2014;103(2):e61-8. https://doi.org/1 0.1111/apa.12469.

12. Singhal A, Cole TJ, Lucas A. Early nutrition in preterm infants and later blood pressure: two cohorts after randomised trials. Lancet. 2001;357(9254): 413-9. https://doi.org/10.1016/S0140-6736(00)04004-6.

13. Zhou J, Shukla W, John D, Chen C. Human Milk feeding as a protective factor for retinopathy of prematurity: a Meta-analysis. Pediatrics. 2015;136(6): e1576-86. https://doi.org/10.1542/peds.2015-2372.

14. Ehrenkranz RA, Younes N, Lemons JA, Fanaroff AA, Donovan EF, Wright LL, et al. Longitudinal growth of hospitalized very low birth weight infants. Pediatrics. 1999;104(2 Pt 1):280-9. https://doi.org/10.1542/peds.104.2.280

15. Cole TJ, Freeman JV, Preece MA. British 1990 growth reference centiles for weight, height, body mass index and head circumference fitted by maximum penalized likelihood. Stat Med. 1998;17(4):407-29. https://doi. org/10.1002/(SICI)1097-0258(19980228)17:4<407::AID-SIM742>3.0.CO;2-L.

16. Freeman JV, Cole TJ, Chinn S, Jones PR, White EM, Preece MA. Cross sectional stature and weight reference curves for the UK, 1990. Arch Dis Child. 1995;73(1):17-24. https://doi.org/10.1136/adc.73.1.17.

17. Shunova A, Bockmann KA, Minarski M, Franz AR, Wiechers C, Poets CF, et al. Choline content of term and preterm infant formulae compared to expressed breast milk-how do we justify the discrepancies? Nutrients. 2020;12(12):3815. https:/doi.org/10.3390/nu12123815

18. Bockmann KA, von Stumpff A, Bernhard W, Shunova A, Minarski M, Frische $B$, et al. Fatty acid composition of adipose tissue at term indicates deficiency of arachidonic and docosahexaenoic acid and excessive linoleic acid supply in preterm infants. Eur J Nutr. 2021;60(2):861-72. https://doi. org/10.1007/s00394-020-02293-2.

19. Bernhard W, Poets CF, Franz AR. Choline and choline-related nutrients in regular and preterm infant growth. Eur J Nutr. 2019;58(3):931-45. https://doi. org/10.1007/s00394-018-1834-7.

20. Bernhard W, Bockmann K, Maas C, Mathes M, Hovelmann J, Shunova A, et al. Combined choline and DHA supplementation: a randomized controlled trial. Eur J Nutr. 2020;59(2):729-39. https://doi.org/10.1007/s003 94-019-01940-7.

21. Faroogi A, Hagglof B, Sedin G, Gothefors L, Serenius F. Growth in 10- to 12year-old children born at 23 to 25 weeks' gestation in the 1990s: a Swedish national prospective follow-up study. Pediatrics. 2006;118(5):e1452-65. https://doi.org/10.1542/peds.2006-1069.

22. Maas C, Mathes M, Bleeker C, Vek J, Bernhard W, Wiechers C, et al. Effect of increased enteral protein intake on growth in human Milk-fed preterm infants: a randomized clinical trial. JAMA Pediatr. 2017;171(1):16-22. https:// doi.org/10.1001/jamapediatrics.2016.2681.

23. Reid J, Makrides M, McPhee AJ, Stark MJ, Miller J, Collins CT. The effect of increasing the protein content of human milk fortifier to $1.8 \mathrm{~g} / 100 \mathrm{ml}$ on growth in preterm infants: a randomised controlled trial. Nutrients. 2018;10(5): 634. https://doi.org/10.3390/nu10050634.
24. Hovi P, Andersson S, Eriksson JG, Jarvenpaa AL, Strang-Karlsson S, Makitie O, et al. Glucose regulation in young adults with very low birth weight. N Engl J Med. 2007;356(20):2053-63. https://doi.org/10.1056/NEJMoa067187.

25. Barker DJ. Fetal origins of coronary heart disease. BMJ. 1995;311(6998):1714. https://doi.org/10.1136/bmj.311.6998.171.

26. Barker DJ, Eriksson JG, Forsen T, Osmond C. Fetal origins of adult disease: strength of effects and biological basis. Int J Epidemiol. 2002;31(6):1235-9. https://doi.org/10.1093/ije/31.6.1235.

27. Doyle LW, Faber B, Callanan C, Morley R. Blood pressure in late adolescence and very low birth weight. Pediatrics. 2003;111(2):252-7. https://doi.org/10.1 542/peds.111.2.252.

28. de Jong F, Monuteaux MC, van Elburg RM, Gillman MW, Belfort MB. Systematic review and meta-analysis of preterm birth and later systolic blood pressure. Hypertension. 2012;59(2):226-34. https://doi.org/10.1161/ HYPERTENSIONAHA.111.181784

29. Blakstad EW, Moltu SJ, Nakstad B, Veierod MB, Strommen K, Juliusson PB, et al. Enhanced nutrition improves growth and increases blood adiponectin concentrations in very low birth weight infants. Food Nutr Res. 2016;60(1): 33171. https://doi.org/10.3402/fnr.v60.33171.

30. Korner A, Kratzsch J, Gausche R, Schaab M, Erbs S, Kiess W. New predictors of the metabolic syndrome in children--role of adipocytokines. Pediatr Res. 2007:61 (6):640-5. https://doi.org/10.1203/01.pdr.0000262638.48304.ef.

\section{Publisher's Note}

Springer Nature remains neutral with regard to jurisdictional claims in published maps and institutional affiliations.
Ready to submit your research? Choose BMC and benefit from:

- fast, convenient online submission

- thorough peer review by experienced researchers in your field

- rapid publication on acceptance

- support for research data, including large and complex data types

- gold Open Access which fosters wider collaboration and increased citations

- maximum visibility for your research: over $100 \mathrm{M}$ website views per year

At BMC, research is always in progress.

Learn more biomedcentral.com/submissions 